HANDBOOK OF BLOOD AND BLOOD PRODUCTS 


\section{Handbook of Blood and Blood Products}

\section{S. GHOSH}

Consultant, East of Scotland Blood Transfusion Service

Ninewells Hospital, Dundee, Scotland

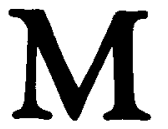


(C) S. Ghosh 1988

All rights reserved. No reproduction, copy or transmission of this publication may be made without written permission.

No paragraph of this publication may be reproduced, copied or transmitted save with written permission or in accordance with the provisions of the Copyright Act 1956 (as amended), or under the terms of any licence permitting limited copying issued by the Copyright Licensing Agency, 33-4 Alfred Place, London WC1E 7DP.

Any person who does any unauthorised act in relation to this publication may be liable to criminal prosecution and civil claims for damages.

First published 1988

Published by

THE MACMILLAN PRESS LTD

Houndmills, Basingstoke, Hampshire RG21 2XS

and London

Companies and representatives

throughout the world

ISBN 978-0-333-47390-0

ISBN 978-1-349-19289-2 (eBook)

DOI 10.1007/978-1-349-19289-2 


\section{Contents}

Preface

$i x$

1. Essential Transfusion Serology 1

Red Cell Antigens and Antibodies: The ABO

System 1

Red Cell Antigens and Antibodies: The Rhesus (Rh)

System 1

Red Cell Antigens and Antibodies: Other Systems 3

Antibody Screening and Cross-matching 3

Leucocyte and Platelet Antigens and Antibodies 5

2. Blood Products: Red Cell Preparations 7

$\begin{array}{ll}\text { Whole Blood } & 7\end{array}$

Red Cell Concentrate $\quad 8$

Reconstituted Blood or Blood with Additive

Solution $\quad 8$

Leucocyte-poor Red Cell Preparations 9

Other Red Cell Preparations $\quad 10$

3. Blood Products: Platelet and Granulocyte Preparations $\quad 15$

Random-donor Platelet Concentrate $\quad 15$

Single-donor Platelet Concentrate 16

Granulocyte Concentrate (Single-donor) 18

Buffy Coat Preparations 19

4. Blood Products: Fresh Frozen Plasma, Albumin Preparations and Plasma Substitutes $\quad 21$

Fresh Frozen Plasma 21

Plasma Protein Fraction (PPF) or Plasma Protein

Solution (PPS) $\quad 22$

Albumin Concentrate $\quad 23$

Plasma Substitutes 24

Oxygen-carrying Blood Substitutes $\quad 27$ 
5. Blood Products: Coagulation Protein Preparations

Cryoprecipitate

Factor VIII Concentrate

Factor IX Concentrate (Prothrombin Complex) 31

Fibrinogen Concentrate

Anti-inhibitor

Other Coagulation Protein Preparations

6. Blood Products: Immunoglobulin Preparations

Human Normal Immunoglobulin (HNI):

Intramuscular

Human Normal Immunoglobulin: Intravenous $\quad 38$

Hepatitis B Immunoglobulin (HBIG) 39

Human Tetanus Immunoglobulin (TIG) 40

Human Varicella Zoster Immunoglobulin (VZIG) 41

Human Rabies Immunoglobulin $\quad 42$

Human Measles Immunoglobulin $\quad 43$

Human Immunoglobulin for Use with Measles

Vaccine

Other Immunoglobulin Preparations

7. Ordering and Administration of Blood and Blood Products

Blood Component Therapy: The Principles 49

Ordering of Blood and Blood Products 50

Specimen Collection $\quad 51$

Routine and Urgent Cross-match Requests 53

The Transfusion $\quad 55$

8. Special Transfusion Situations 61

Emergency Transfusion $\quad 61$

Massive Transfusion $\quad 62$

Multiple Transfusions $\quad 64$

Irradiated Blood Products $\quad 65$

Autologous Transfusion $\quad 66$

Refractoriness to Random-donor Platelets $\quad 67$

Transplant and Transfusion $\quad 68$

Blood Transfusion in Autoimmune Haemolytic

Anaemia (AIHA) 
9. Neonatal Transfusion and Treatment and Prevention of Haemolytic Disease of the Newborn (HDN) 71

General Considerations $\quad 71$

Blood for Neonatal Transfusion and its

Administration $\quad 72$

Top-up Transfusion (Replacement Transfusion) $\quad 73$

Exchange Transfusion $\quad 73$

Use of Fresh-frozen Plasma $\quad 75$

Platelet Transfusion $\quad 75$

Granulocyte Transfusion $\quad 76$

HDN: Its Prevention and Management 76

10. Use of Blood Products in the Management of

Coagulation Disorders

General Considerations $\quad 83$

Congenital Bleeding Disorders 83

Acquired Bleeding Disorders $\quad 88$

11. Adverse Reactions to the Transfusion of Blood and Blood Products

Introduction and Classification 91

Acute Haemolytic Transfusion Reaction 92

Febrile Transfusion Reaction $\quad 94$

Allergic Reactions 95

Circulatory Overload 96

Other Immediate Complications 97

Delayed Haemolytic Transfusion Reaction 97

Viral Hepatitis 98

Acquired Immunodeficiency Syndrome (AIDS) 98

Other Delayed Transfusion Complications 99

12. Blood-Ordering Schedule for Surgery (Guidelines) 103

13. Us $\simeq$ of Cell Separators 107

Further Reading 111

Glossary 113

$\begin{array}{ll}\text { Index } & 115\end{array}$ 


\section{Preface}

This small book is designed to provide junior medical staff with a convenient reference for blood transfusion therapy. The emphasis is on the management of patients and the rational use of blood and blood components, but it does not provide details of technical or theoretical aspects. However, I hope that anyone who is involved in the use of blood or blood products, but not directly involved in the subject, will find it extremely useful.

In the preparation of this book I have consulted and included factual material that is readily available in most of the standard textbooks. Some of these are listed as further reading, and should be referred to as necessary for further information on particular topics.

I wish to thank Drs E. Brookes and M. Davies for their advice, and Mrs Anne Adamson for her patience in typing the manuscript.

Dundee, 1987

S. G. 